\title{
RESILIENCE PROCESSES WITHIN THE SCHOOL CONTEXT OF ADOLESCENTS WITH SEXUAL VIOLENCE HISTORY ${ }^{1}$
}

\author{
Alex Sandro Gomes Pessoa" \\ University of Western São Paulo (UNOESTE), Presidente Prudente - Sao Paulo, Brazil \\ Renata Maria Coimbra** \\ Sao Paulo State University (UNESP), Presidente Prudente - Sao Paulo, Brazil \\ Dorothy Bottrell ${ }^{* * *}$ \\ Victoria University, Melbourne, Australia \\ Amity Noltemeyer ${ }^{* * * *}$ \\ Miami University in Oxford, Ohio, USA
}

\begin{abstract}
This study examines the school context of adolescents with a sexual violence history, highlighting their perceptions of protective and vulnerability mechanisms within a social ecological resilience framework. The study was conducted in a youth service agency located in a mid-sized city in the inner of Sao Paulo state. Initially, 31 male and female adolescents victims of sexual violence, aged 12-18, answered survey items assessing resilience processes. Based on their responses, a subgroup of seven adolescents was selected to participate in individual semi-structured interviews addressing the role of school in their lives. Five key themes were identified in the data, with two overarching categories emerging: 'evaluation of school structure' and 'formative processes through diversity and difference'. Exploration of interview excerpts within these categories revealed that schools occupy an ambivalent space in terms of risk and protective factors in the participants' lives, with predominately negative social indicators emerging.
\end{abstract}

Keywords: Resilience. Sexual violence. School. Risk. Protection.

${ }^{*}$ PhD, Associate Professor in the Psychology Department and Professor at the Graduate Program in Education at The University of Western São Paulo (UNOESTE), Presidente Prudente, Sao Paulo, Brazil. E-mail: < alexpessoa2@gmail.com>.

"PhD, Associate Professor in the Pedagogy Department and Professor at the Graduate Program in Education at Sao Paulo State University (UNESP), Presidente Prudente, Sao Paulo, Brazil.

"..Senior Lecturer in Social Pedagogy in the College of Education at Social Pedagogy Department at Victoria University, Melbourne, Australia.

...*PhD, Associate Professor in the Educational Psychology Department and Coordinator of the School Psychology Program at Miami University in Oxford, Ohio, USA. 


\section{PROCESSOS DE RESILIENNCIA NO CONTEXTO ESCOLAR DE ADOLESCENTES COM HISTÓRICO DE VIOLÊNCIA SEXUAL}

RESUMO: Esta pesquisa investiga o contexto escolar de adolescentes com histórico de violência sexual, enfatizando suas percepções em relação aos mecanismos de proteção e vulnerabilidade a partir de abordagem ecológica de resiliência. O estudo foi realizado em um programa social localizado numa cidade do interior do estado de São Paulo. Inicialmente, 31 adolescentes, de 12 a 18 anos, de ambos os sexos e com histórico de violência sexual responderam um questionário que avaliou os processos de resiliência. Baseado nessas repostas, um subgrupo de sete adolescentes foi selecionado para participar de entrevistas semiestruturadas que versavam sobre o papel das escolas em suas vidas. Cinco temas foram identificados a partir desses dados, abrangendo duas categorias nomeadas como "avaliação da estrutura escolar" e "processos formativos através da diversidade e diferença". A exploração dos conteúdos das entrevistas revelou que as escolas ocupam um espaço ambivalente em termos dos fatores de risco e proteção na vida dos participantes, predominando indicadores sociais negativos.

Palavras-chave: Resiliência. Violência sexual. Escola. Risco. Proteção.

\section{BACKGROUND}

In recent years, there has been increased attention to the role of schools in identifying cases of sexual violence. Many countries, including Brazil, have established mandatory reporting policies as well as programs that promote self-protective behaviors in children and adolescents (Brino \& Williams, 2009, 2008; Estatuto da Criança e do Adolescente, 1990; Faleiros \& Faleiros, 2008; Mathews, 2010). According to the UN Convention on the Rights of the Child, ratified by Brazil in 1990, educational measures assessment comprises one form of protecting young people from all forms of violence, including sexual abuse. Relatedly, Brazil's Child and Adolescent Act (1990) provided the basis for rights-based policy shifts in Brazil including greater protection of vulnerable youth, for example, through establishing a broader range of programs and facilities with a socioeducative focus (Morrison, Nikolajski, Borrero, \& Zickmund, 2014). To date, however, there remains a paucity of research on how schools support students with a history of sexual violence and operate protectively to minimize the impact of violence in students' lives.

This paper contributes to understanding protective mechanisms in school contexts through the lens of resilience, based on analysis of the accounts of a small group of students attending public schools in Sao Paulo State, Brazil, all of whom had been victims of sexual violence. In this analysis, sexual violence and resilience 
are conceptualized ecologically. Sexual violence against children and adolescents, including sexual abuse and sexual exploitation, refers to any sexual act performed by an adult or person of more advanced psychosexual maturity, which has the objective of obtaining satisfaction through the use of children and adolescents' bodies (Habigzang, Ramos, \& Koller, 2011; McElvaney, Greene, \& Hogan, 2011). Sexual violence is a violation of a person's rights and dignity, misuse of power in victimization, and is related to social inequalities, including poverty, social exclusion and especially gender inequalities (Beckett \& Schubotz, 2014; Ricardo \& Barker, 2008). Feminist and community psychologists' ecological analyses of sexual violence trauma thus emphasize that social contexts, power relations, cultural norms and structures that support discrimination and violence are integral elements of resultant personal vulnerabilities and need to be incorporated into intervention designs (Carmody, 2009; Dutra-Thomé, Santos, \& Koller, 2011; Harvey, 1996; Howell, 2011; Tseris, 2013a). This ecological conceptualization aligns with contemporary understandings of resilience.

The concept of resilience has been intensively discussed by the academic community, especially by professionals studying human development under conditions of psychosocial risk, including sexual violence. Despite epistemological differences in the theoretical approaches to resilience, a common focus is the quest for understanding the psychological resources that ensure positive trajectories of wellbeing for individuals and groups, even when they face significant adversity that is commonly associated with trajectories of vulnerability (Harvey, 1996). Resilience studies have identified a broad range of individual and contextual (e.g., in families, communities, services) protective factors associated with buffering, restorative and growth-promoting processes (for example, see Masten, 2014a; Noltemeyer \& Bush, 2013). According to Pesce, Assis, Santos and Oliveira (2004), protective processes produce a catalytic modification on an individual's response to risk processes.

In designing this study, resilience was understood to be a dynamic process (Koller, 2004; Yunes, 2003; Yunes \& Szymanski, 2001) that involves the individual's capacity to deal positively with adversity and the community's capacity to provide meaningful resources (Ungar \& Liebenberg, 2011), in the presence of traumatic events that threaten people's wellbeing (Sapienza \& Pedromônico, 2005). This conceptualization has been applied to individuals, groups, communities and cultures marked by varied risk factors, oppression, and natural disasters, as well as to analyses of recovery and growth after sexual violence. Across diverse contexts, resilience may be comprised of many 
unique protective factors for individuals affected by trauma (Masten, 2014b), though there also appear to be universally identifiable global clusters of protective factors in resilience processes (Ungar, 2008).

Ungar et al. (2007) developed a social ecological framework of resilience that highlighted the complex interplay of homogeneous contextual and heterogeneous individual aspects of resilience. The International Resilience Project (IRP) included young people from 14 diverse, mainly non-Western contexts across five continents who experienced a broad range of adverse and traumatic circumstances including substance abuse, breakdown of relationships within their families, racial or ethnic marginalization, poverty and exposure to violence and war. The IRP identified seven 'global' clusters of factors and processes found to serve a protective function for individuals experiencing diverse psychological, social and contextual adversities: 1) Access to material resources (i.e., availability of basic resources for development); 2) Relationships that are meaningful and supportive; 3) Identity (i.e., sense of purpose and individual and social strengths, weaknesses and values); 4) Power and control (i.e., ability to make decisions and act for change); 5) Cultural adherence (i.e., engagement in local cultural practices); 6) Social justice (i.e., finding meaningful roles and experiences related to social equality); 7) Cohesion (i.e., feeling part of something bigger and a sense of social or spiritual responsibility). The IRP research also found patterns of resilience that reflected the specific contexts, available resources and young people's agency in dealing with adversities. Thus, not all global aspects were found for every individual and global aspects of resilience clustered together in heterogeneous ways across contexts (Ungar et al., 2007).

In order to further contribute to the resilience literature, this article analyses the school context of adolescents with a sexual violence history, articulating their perceptions of the resilience factors and processes identified by Ungar et al. (2007). In the following sections, we discuss key factors and processes identified in resilience studies related to sexual violence and argue that there is an alignment of these protective mechanisms with those identified in studies of school contexts. Although school-based resilience studies have mainly focused on "youth at risk" as a broad category, incorporating socioeconomically disadvantaged and marginalized groups, we suggest that global school protective factors and processes may be salient to the resilience of young people with a history of sexual violence. Based on the young peoples' accounts, as detailed in subsequent sections, it will be argued that both school structures and everyday practices are critical contributors to resilience. 


\section{SEXUAL VIOLENCE AND RESILIENCE}

The literature reveals significant variability in the impact of sexual violence on individuals, with effects including emotional, social and affective vulnerabilities (Carroll-Lind, Chapman, \& Raskauskas, 2011; Deb \& Walsh, 2012; Nelson et al., 2011). Short- and longterm effects may vary according to the victim's age, relationship to perpetrator, and severity of abuse (Marriott, Hamilton-Giachristis, \& Harrop, 2014). Health consequences commonly reported in the literature include higher rates of sexually transmitted infections, substance abuse, depression, anxiety, psychological disorders, low self-esteem, difficulties in relationships, suicidal ideation, and social functioning related to trust, feelings of isolation and stigma (Browne \& Finkelhor, 1986; Polusny \& Follette, 1995; Zhu et al., 2015).

Despite these troubling findings, approximately fifty percent of adolescent survivors of sexual abuse do not develop serious psychological or behavioral problems (Edmond et al., 2006; Leech \& Littlefield, 2011). Resilience research has been important in accounting for this absence of adaptive problems in young people. Studies have highlighted social support, inner resources (e.g., coping skills, self-esteem), family relationships, friendships, and community resources as key protective factors for individuals with a history of sexual violence (Marriott et al., 2014).

Social support has been found to be a key protective factor associated with recovery, maintenance of positive self-esteem and post-traumatic growth following experiences of sexual violence, for both males and females (Collishaw et al., 2007; Harper et al., 2005; Jordan, 2009; Kia-Keating, et al., 2010; Tremblay et al., 1999). Similar to Werner's (1993) seminal finding that a significant adult outside the family could provide powerful support that fostered resilience in "high risk" young people, Tremblay et al., (1999) and Jordan (2002, cited in Jordan, 2009) found significant others outside the family provided the strongest protection against detrimental effects of childhood sexual abuse. Survivors' experience of others' empathy and belief in them, as well as their practical care, reduces feelings of isolation and promotes resilience in terms of everyday coping, regaining self-esteem and restoring relational capacity (Harvey, 1996; Kia-Keating, et al., 2010). Social support is crucial to the process of survivors rebuilding trust and feeling safe in their relational world. These restorative processes enable the individual to make new meaning of the trauma. For example, youth with social support can begin to regain trust and discard self-blame or a sense of a 'damaged self' (Harvey 1996, p. 13), while personal strength and compassion re/emerge. 
The few resilience studies specifically focused on school-based protective factors for young people with a history of sexual violence have similarly highlighted social support and its interrelationship with individuals' positive outlook on their future. Lower levels of psychological distress in the face of sexual violence are associated with academic success and positive relations with teachers, other school staff and peers (Hébert et al., 2013; Leech \& Littlefield, 2011; Luster\& Small, 1997). Edmond et al. (2006) associated girls' resilient trajectories with positive peer groups and optimistic views about the future, specifically, the girls' confidence in their plans to complete high school and go on to higher education.

Personal empowerment is a resilience generating process that promotes recovery and growth after sexual violence and is instrumental to maintaining long-term psychological wellbeing. Empowerment involves experiencing a sense of control attained through formal legal redress and/or maintaining everyday routines, activities, relationships, "pushing through" difficulties and "not giving up" (Tseris, 2013b). Having a sociopolitical framework for understanding sexual violence enabled young women in Tseris' (2013b) study to critique gendered power relations and to experience empowerment by expressing their standpoint in everyday contexts (e.g., challenging sexist or misogynistic remarks made by peers). Similarly, personal empowerment may be expressed in stepping up to help others in difficult times while contributing to "self-healing" (Kia-Keating et al., 2010). Empowerment as an important asset to recovery and growth is also related to social support. For example, Banyard (1999) found that the resilience of mothers who had experienced childhood sexual abuse related to two main factors of internal locus of control, evident in personal problem-solving, and having the support of a confidante. Empowerment is thus interrelated with social, emotional and practical support as these processes facilitate the individual's re/ gaining control over her life, and relational trust provides a basis for growing confidence in one's own agency (Harvey, 1996).

The opportunity to pursue personal interests is an important resilience process. Harper et al. (2005) stress the value of engagement in constructive everyday activities (e.g. socializing, outings, gardening, and swimming) and creative pursuits (e.g. painting, journaling, music) in life realms perceived to be unrelated to recovery or past abuse. This was understood by child abuse survivors as an element of selfcare promoting wellbeing. Similarly, pursuing creative interests was identified by young women as resilience promoting in the context of sexual violation (Tseris, 2013b). Resuming or taking on new activities 
may be a means of re-framing life perspectives and priorities and envisioning a positive future as new possibilities arise through the agentic action, cognitive engagement and meaning-making involved in these pursuits (Calhoun \& Tedeschi, 2006; Harvey, 1996). This process is related to empowerment in providing an opportunity in which to exert control, develop problem-solving and focus on the achievement of personal goals. Janoff-Bulman (2006) argues that these transformative processes provide a buffer to subsequent psychological stressors and trauma effects.

\section{SCHOOL PROCESSES OF RESILIENCE AND VULNERABILITIES}

Although not focused on resilience specifically related to sexual violence, school-based resilience research involving 'at risk' youth suggests that in addition to being a strong source of social support, schools may be sites of young people's empowerment and opportunities to pursue their interests. Learning is empowering when it is meaningful to students, enables them to achieve personal goals, is mediated through skill development and self-efficacy (Maton, 2008), and is promoted through collaborative groups, choices and recognition of student voice throughout school decision-making structures (Henderson, 2012; Maton, 2008; Travis \& Leech, 2013). Through formal curricula, extracurricular activities and student led projects, schools may provide opportunities for young people to discover and develop their interests and talents and to gain a sense of their own and collective problem-solving capacities (Gilligan, 2000; Masten et al., 2008). These resilience processes foreground the interrelationship of young people's capacities and agency, teacher responsiveness and inclusive school culture. Drawing on a broad international literature, Clark (2014) emphasizes that inclusion is an overarching cultural feature of resilience promoting schools and it appears to underpin both empowerment and meaningful opportunities. Inclusion is exemplified in teachers' belief in all students as competent learners, shared decision-making and actions to ensure safe, respectful and equitable learning spaces (Kirk et al., 2015).

Positive transformation of vulnerabilities related to sexual violence may occur through 'catalytic' or 'cascading' processes. 'Cascading' (Masten et al., 2008) is the linking and harnessing of individual strengths and social resources. In the school context, as protective factors impact a specific capacity or domain, the outcome may be a catalyst or conduit of further buffering, restoring or promoting growth as young people interactively activate or tap 
other strengths and resources. For example, cultivating a culture of collaboration that strengthens students' sense of belonging and participation in decision-making can also strengthen students' selfesteem, self-efficacy and relational confidence (Pfeiffer \& Salvagni, 2005). Additionally, as a normative everyday setting, the school may be a restorative place because it is a "separate" realm of a young person's life (Harper, et al., 2005), where being a student and classmate provides identities, activity and relationships promotive of the individual's sense of self as competent, agentic, connected and continuing to develop academically and personally.

Although evidence of resilience factors and processes in school contexts are relevant to young people with a history of sexual violence, resilience studies have also highlighted school processes that may undermine resilience, increase vulnerabilities and effectively constitute further adversities with which young people must cope. These studies point to the significance of school resources, power relations, cultural norms and structures that fail to provide adequate student support or intervene to eliminate discrimination and bullying. For example, as learning and achievement constitute the 'core business' of schools, academic adversity may be the most significant barrier students face, with cascading impacts on other aspects of their schooling experience (Martin \& Marsh, 2006). When school systems fail to provide the necessary resources and young people are not able to access the learning support they need, their academic resilience may be diminished and ultimately transform into school disengagement or 'resistance' (Bottrell, 2007; Bottrell \& Armstrong, 2012). Bullying, sexual harassment, racism and homophobia may not only impede students' academic resilience and achievement but may also diminish their sense of belonging, contribute to their disengagement from schooling and detrimentally impact their physical and mental health (Zins, Elias \& Maher, 2007). Moreover, conservative models of teacher-directed instruction may provide fewer opportunities for young people to participate in decision-making, pursue their chosen interests and engage in collective projects.

School processes are thus significant to trajectories of both resilience and vulnerability. The impact of schooling is multi-layered in providing resources for resilience including those specifically relevant to recovery and growth after sexual abuse as well as more global catalytic or cascading elements that can enhance students' capacities, skills, relationships, empowerment and opportunities. The present study centers young people's own accounts of the most significant factors and 
processes within school contexts that foster the resilience of students with a history of sexual violence. Their insights and critiques foreground the interrelationship of vulnerability and resilience generating practices.

\section{METHODOLOGY}

The qualitative and exploratory study reported here was conducted in a medium-sized city located in Sao Paulo State, Brazil. The population of the city was estimated to be 207.250 habitants in the last survey conducted by the Brazilian Institute of Geography and Statistics (2010) and its Human Development Index (HDI) score was 0,846, which is considered high in comparison to the other cities in the state. This research was part of a larger mixed-methods study that aimed to analyze the role of schools for adolescents exposed to sexual violence, considering both cases of abuse and exploitation (PESSOA, 2011), though the perspectives discussed here are those of young people who all had a history of sexual abuse, having been victimized by immediate or extended family members (father, uncle, brother) or significant others close to the young person or their family (neighbor, boyfriend).

\section{PARTICIPANTS AND PROCEDURES}

The study comprised interviews with seven 12 to 18 year-old adolescents who were identified as resilient, attended public schools, and responded to the invitation to participate. In order to identify these seven resilient adolescents for participation in the study, 31 adolescents were recruited through a youth service that provides therapeutic and educational services to young people under eighteen who have been victims of sexual violence. Each of the 31 adolescents completed a resilience survey, the Child and Youth Resilience Measure (CYRM; Ungar \& Liebenberg, 2011). This measure has been internationally validated through cross-cultural research and identifies resilience in terms of internal and external assets relevant to positive development despite risk exposure in diverse cultural contexts. It consists of 28 items across 3 sub-scales of individual strengths (awareness of personal strengths, social and problem-solving skills), quality of interpersonal relationships (family support, caregiver supervision) and contextual support (of community, spiritual or affiliation, school support and relevance). Participants were assigned to three distinctive high to low resilience groups on the basis of non-hierarchical cluster analysis 
of the survey results. The seven high resilient youth reported more positive responses indicative of resilience processes with a median score of 4.36 on the 5.00 point scale. Table 1 provides demographic information on each of these participants:

TABLE 1 - Demographic information of participants

\begin{tabular}{|c|c|c|c|c|c|c|c|}
\hline Name $^{*}$ & Gender & Age & $\begin{array}{c}\text { Ethnicity } \\
\text { self- } \\
\text { reported }\end{array}$ & $\begin{array}{l}\text { Monthly } \\
\text { income }\end{array}$ & $\begin{array}{l}\text { Schools } \\
\text { atended }\end{array}$ & $\begin{array}{l}\text { History } \\
\text { of school } \\
\text { failure }\end{array}$ & $\begin{array}{c}\text { Sexual } \\
\text { agressor }\end{array}$ \\
\hline Augusto & Boy & 15 & White & $\begin{array}{l}\text { More than } \\
R \$ 1200,00\end{array}$ & Public & Yes (2 times) & Father \\
\hline Bianca & Girl & 12 & Black & $\mathrm{R} \$ 700,00$ & Public & No & Uncle \\
\hline Débora & Girl & 14 & White & $R \$ 1100,00$ & Public & No & Neighbor \\
\hline Lígia & Girl & 14 & White & $\mathrm{R} \$ 900,00$ & Public & No & Uncle \\
\hline Tatiana & Girl & 13 & White & $\begin{array}{l}\text { More than } \\
R \$ 1200,00\end{array}$ & Public & No & Uncle \\
\hline Valentina & Girl & 14 & Black & $R \$ 150,00$ & Public & No & Brother \\
\hline Valéria & Girl & 15 & White & $R \$ 350,00$ & Public & No & Boyfriend \\
\hline
\end{tabular}

${ }^{*}$ Names are pseudonyms selected by each participant.

\section{MEASURES}

This qualitative study used semi-structured interviews, with questions grounded in the theoretical approach of the seven global factor clusters identified by Ungar et al. (2007). Table 2 summarizes the questions across the seven global factors. 
TABLE 2 - Semi structured interview script

\begin{tabular}{|c|c|}
\hline Global Factors & Questions \\
\hline Access to resources & $\begin{array}{l}\text { How would you evaluate the quality of your school? Do you have } \\
\text { necessary materials and resources to learn there? }\end{array}$ \\
\hline School relationships & $\begin{array}{l}\text { Who are the most important people to you meet at school? If you } \\
\text { have any problem in your life, can you find support in the school to } \\
\text { deal with it? }\end{array}$ \\
\hline Student identity & $\begin{array}{l}\text { Are you able to solve and develop the academic activities presented } \\
\text { in the school? }\end{array}$ \\
\hline Empowerment & Can you express yourself during your classes or in other situations? \\
\hline School culture & $\begin{array}{l}\text { Do you feel that you belong to school? Do you like to be there, and } \\
\text { enjoy its traditions and routines? }\end{array}$ \\
\hline Social justice & $\begin{array}{l}\text { Have you seen any kind of injustice in the school? Does your school } \\
\text { offer appropriate services for young people? }\end{array}$ \\
\hline Cohesion & $\begin{array}{l}\text { Is the school important for people who are living in your community? } \\
\text { Why? Can the schools help to change positively someone's life? }\end{array}$ \\
\hline
\end{tabular}

These questions aimed to evoke the adolescents' perception of the factors and dynamics of the school context that could be articulated with global resilience processes, while providing scope for young people to specify what they perceived as the most significant contextual factors and dynamics of their schooling context. Interviews were conducted by the first author, as individual, single sessions lasting 50 minutes, in the youth service agency where young people were comfortable. Interviews were conducted in Portuguese, and were digitally recorded and transcribed in full by the first author who is biliterate in Portuguese and English. Initial analysis was conducted by the first author in Portuguese and large selections of the text were translated into English and discussed with the third and fourth authors. 


\section{HUMAN SUBJECTS PROTECTIONS}

The study procedures were approved by Ethics Committee from $(323 / 2008)$, and complied with ethical guidelines for scientific research. Young people and their parents gave voluntary consent to participate. This included consent to obtain information from staff on the nature of the sexual violence they had experienced. The signed consent forms were collected from the parents or legal guardian during meetings in the youth service agency or were provided to us by the adolescents who obtained the signatures themselves in their homes. To preserve the anonymity of the participants, the names used in this paper are pseudonyms chosen by the adolescents themselves.

\section{DATA ANALYSIS}

Interview data were systematically analyzed using groundedtheory (Strauss \& Corbin, 1990) procedures. After open coding, five sub-categories or key themes were identified, and finally, two new categories emerged: 'evaluation of school structure' and 'formative processes through diversity and difference'. Next, two researchers who did not participate in any stage of the research and with proven experience in the field of research involving populations of youth at-risk were consulted to analyze the relevance of the categories, as well as to assess whether the excerpts of interviews were properly used to illustrate them. Concordance rates were satisfactory $(94.44 \%$ for category 1 and $95.45 \%$ for category 2 ). All themes were analyzed by the evaluators and those which resulted in disagreement were removed from the data analysis.

\section{RESULTS AND DISCUSSION}

\section{Evaluation of School Structure}

The first category, 'Evaluation of school structure', was derived from three major themes of young people's accounts. These themes highlighted systemic or structural deficiencies and some aspects of schooling that are meaningful to the young people. The quotes included in Table 3 illustrate how the participants understand the school model, as well as educational practices conducted within the institution. 
TABLE 3 - Evaluation of school structure

Themes

Supporting quotes

Spaces and

resources availabe

Engagement in

educational activities
Débora: There is no way to do chemistry experiments in the classroom. Our school needs a lab and a better library.... because the library we have we do not even use... it is full of can of painting. The books there we've already read or are not related to what we are learning in school. The school has a computer room, but I have no contact with it; only the students enrolled at night use it. Since the beginning of the year we have never been able to use the computer lab.

Tatiana: The school has a computer room. But almost nobody uses it, because the computers are too old.

Valéria: We have the space there [for a lab], but there's we are not able to do experiments. There are specific tables and reservoirs but you can't find the liquids necessary. They use the chemistry room for keeping the music instrument and to store the old books we don't even use anymore.

Augusto: "It depends on the subject I find difficult. I'm the worst student in mathematics. Nobody told me that. But I think I am the worst student. "

Lígia: We usually do theater but I've never been. I don't like it. I don't think it's cool. I was planning on attending this year, but I am so ashamed to stand in front of everyone. In my classes I love to present in front the classroom and explain my work up front. But not in the theater. The last year we had classes, my girlfriends danced too, but I did not participate.

Tatiana: I have difficulties in History. I do not understand anything the teacher says and I do not understand anything. I think it's my fault, because I do not pay attention enough.

Valentina: Sometimes in physical education classes I can throw a ball, make a few things. When I have time. But I think I can do it. I always go there to ask for help if I do not understand. I'm also getting good grades on tests. I like all subjects but my favorite is English. 
TABLE 3 - Evaluation of school structure (continuation)

Criticism of conservative models
Bianca: Because when girls dance funk, they want to lie around and sway, and it's not allowed at school. Neither here nor in the other schools I've studied in. I think in almost any school it is not allowed. I think it's silly, because there's nothing wrong with dancing.

Débora: The students asked the principal, "Ms. Marta, why do you come only once a week in school? ". She said, "Because I teach in another school." We asked, "And why did you take a position here that you are not able to carry on?". She got really angry. We asked her if she did not like hearing the truth. She was so mad with us and ordered everyone out of the room.

Lígia: In my school never had it [situation or spaces to make decisions collectively], never witnessed it. Never saw it. They decided everything without asking our opinion. But I think they should do some research to see what is needed. They even did at first, but then nothing happened. I think it is not like that.

Tatiana: Sometimes we think about doing a project and talk to the principal. We think it will be easy and she will say yes. But she says no. This happened earlier in the year. We developed a project to make our own t-shirts and we had the money to do it. But she said no. She said if she allowed us to do, all the students would want to. We all were angry.

The theme entitled 'spaces and resources available' revealed that although schools have places like libraries and computer labs, they are insufficiently utilized due to inadequate materials for developing educational activities. In addition, some spaces are used for non-educational purposes, such as a chemistry lab that was used as a warehouse. Participants also reported a lack of maintenance of equipment and inaccessibility to educational technology.

These data indicate the need for reflection on the educational and structural resources available in schools, as well as their proper use. Schools that cannot fund structural resources such as technological environments and labs may have a role in intensifying degradable livelihoods of social groups affected by violence. Given the possible social and psychological damage of sexual violence, schools that do not offer quality resources to students can produce school failure, enhancing an embrittlement of these subjects, since poor and limited educational resources lead to academic and social lags (Oliveira \& Araújo, 2005). 
Regarding engagement in educational activities, participants openly expressed their perceived personal limitations but also revealed barriers to academic resilience due to low involvement with the disciplines. The students did not identify their role as co-responsible when they failed to learn. This was perceived as a unique responsibility and deficiency in themselves. Nonetheless, there were also accounts of positive feelings associated with particular school subjects.

The finding of discourses that assign exclusive responsibility to the adolescent by not learning school subjects, without considering other factors associated is worrying. These aspects also reveal several psychological implications, since participants can somatize these perceptions with the false idea of responsibility for the occurrence of sexual violence (Habigzang, Ramos, \& Koller, 2011), routinely reported by victims. In this sense, accountability and individualization of school failure, which should be understood as a social production (Asbahr, 2011), can contribute to consolidating negative feelings about these youth's identities. On the other hand, engaging in educational activities that bring personal meaning, as presented by some participants, can contribute to reframing the sexual abuse, since it mobilizes youth's positive ideations, directing them to trajectories of resilience.

Some notions were also critical of a conservative model of school that ignores students' perspectives. For example, participants described boycotts of activities proposed by students. According to one interviewee, when they are not listened to at school, a sense of anger arises, especially for not being able to accomplish projects organized collectively by students.

In another case, the criticism directed to the principal by the students was not accepted, generating a malaise and a very negative reaction, which included a change in the participant's voice tone and the request for students to withdraw from a deliberative committee that mandatorily must be composed by all the segments at schools, including students. One adolescent also criticized the fact that some cultural practices (e.g., funk) are not allowed at school. According to her, the justifications used to restrict such practices are not plausible and carry stereotypes guided by sexist discourses.

Educational models that are based on a traditional paradigm may not recognize the complex needs of adolescents with a history of sexual abuse. Thus, new assumptions and progressive educational perspectives should be considered (Paro, 2011), including strategies to decrease hierarchical relations within the institution. An alternative is to value the participation of adolescents in deliberative committees 
at schools. Opening up spaces for dialogue can enhance the feeling of belonging (Brooks, Magnusson, \& Spencer, 2012) and the perception that there are spaces for young people express their opinion. It can have important implications in terms of the building of identity and social participation (Bolzan \& Gale, 2011; Bottrell, 2009), especially for those who have been silenced by forms of violation of their rights, such as the participants in this study.

\section{Formative Processes through Diversity and Difference}

The second category, 'Formative processes through diversity and difference', includes topics that extend beyond scientific content of subjects. It is linked to experiences in the school environment that allow the adolescents to appropriate values indispensable to the establishment of interpersonal relationships, mainly through diversity and difference. The quotes in Table 4 illustrate how participants understood these formative processes through diversity and difference.

TABLE 4 - Formative processes through diversity and difference

Experiences of Altruism
Augusto: I help. For example, I helped a guy with down syndrome. He entered the school because they could not find a special school for him. The boys in the fifth and eighth grade were kidding him, spinning, clapping his eyes. Once I took a beating to help him. I said to them, "He has a mental problem and he can even sue you." They beat me and everyone was sent to talk to the principal. But l'd do it again.

Debora: In my school has a girl in a wheelchair. She suffered a lot to be able to go to class because she has to climb stairs. We help her. As I am stronger and she is quite chubby, I had to take her in my arms.

Lígia: Wow, it hurts me. There are people there that I love and do it with a friend hurts too much [being bullied]. And I do not like it when someone messes with my friends. For example, if I go out with a friend and a guy messes with her, l'd rather he mess with me than with her.

Tatiana: Because I put myself in their place. Imagine you being called something you're not. 
TABLE 4 - Formative processes through diversity and difference (continuation)

Valéria: For example, back in my school, what I see a lot is when people get hurt. Always have someone to help. Another thing ... there is a girl at my school who has a disability. We always help her. If she is going up the stairs, we help. If she wants to go to the bathroom or drink water, we help her. We're always helping and always around her. Because sometimes, some jokers mess with her. So, we are always around her.

Discriminatory practices
Bianca: Sometimes people make jokes about skin color. I have suffered prejudice. Because people say I'm chubby. But I do not care. People say, "Get out, you're fat." Sometimes people say you're lesbian just because you're embraced with a friend of yours.

Ligia: I have gay friends. I've seen them be made fun of and did not like it. He cried, you know? They began to diss him, calling him gay. He came out crying and didn't talk to the principal because he did not want more trouble. It hurts to me a lot.

Tatiana: I have a friend who weighs $100 \mathrm{~kg}$. She is quite big and everyone is prejudiced against it. She suffers from several things. I feel bad, you know?

The findings revealed that the school environment fosters participants' altruistic relationships, especially with regard to issues of diversity that encompass inclusive practices for people with disabilities or in terms of attitudes contrary to racial discrimination and homophobia. Proponents of the theoretical approach known as positive psychology point to the psychological and social implications of positive feelings, including altruism, which can offset the negative impact of problematic and conflictual situations (Seligman, 2011; Soosai-Nathan, Negri \& Fave, 2013), as in the case of sexual abuse.

The ability to put oneself in another's place and oppose practices of social injustice can indicate personal strength, and therefore may be associated with resilience. It is important to note that this attitude does not necessarily come from an intentional structured practice of the current school model, but it can be linked to other experiences of adolescents outside the institution. However, based on interview excerpts, it is necessary to recognize that the school can constitute a prime place for the development of relations permeated by altruism and acceptance of diversity. 
Examples of repudiation of prejudice were cited, as well as negative feelings arising from unfair relations occurring in the school context. Relatedly, very accurate descriptions emerged of repudiation of peer violence characterized by issues of sexual identity and disrespect for diversity. The interviews show that the type of help offered by the participants may vary from mobility assistance (e.g., climbing stairs) to opposing forms of violence. In seeking to protect friends, some participants even claim (altruistically) to prefer certain situations to occur with themselves. They add that it is distressing to see someone you love suffering.

The data obtained related to prejudice at schools suggest a strong variable which can represent vulnerability for adolescents with a history of sexual violence. Discriminatory practices in the institution exacerbate the negative elements of subjectivity established due the experience of sexual abuse, especially when referring to contents of sexuality and corporeality (Kremer, Orbach, \& Rosenbloom, 2013; Rodrigues, Brino, \& Williams, 2006).

\section{Dialectical interrelationship between resilience and vulnerability in the school context}

The data brought to light some elements underexplored by the literature in regard to school processes of resilience for victims of sexual violence. Figure 1 was constructed to represent the central issues identified by participants including those processes that could influence trajectories of vulnerability as well as protection.

FIGURE 1 - Resilience and vulnerability within the school context for adolescent victims of sexual violence

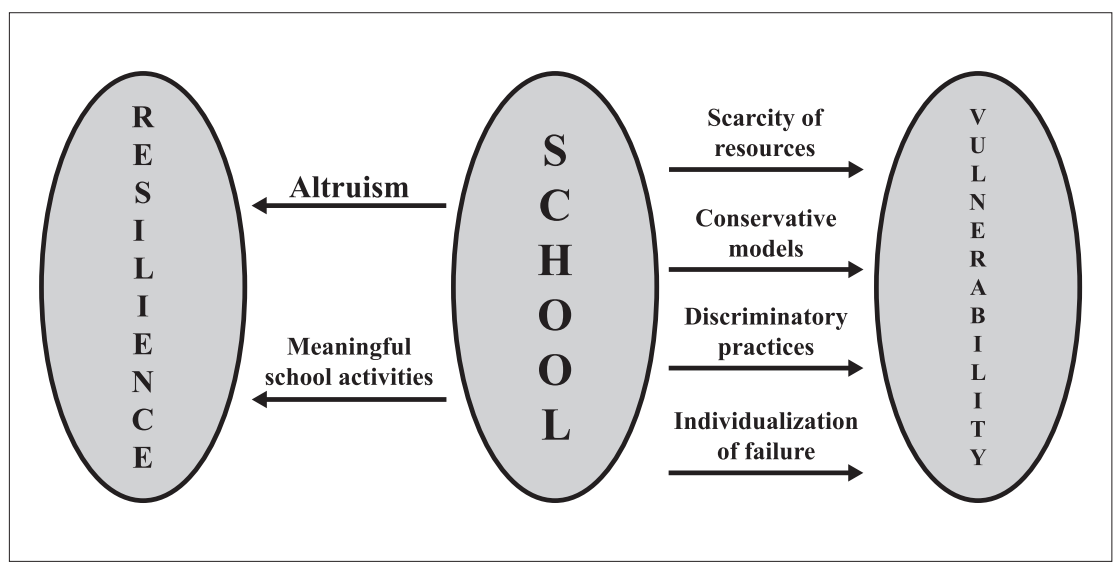


The young people's views confirmed the importance of meaningful learning activities as previously identified in the resilience literature (eg Maton, 2008). This was evident in both their affirmation of activities that connect curriculum with personal interests and their critique of the lack of opportunity to pursue more of the cultural and social activities that engage their interest. However, altruism, as the other significant process young people associated with trajectories of resilience, is relatively unexplored in the resilience literature, though our findings suggest it is closely connected with social support that is identified in the literature as a key factor in school-based resilience and the resilience of young people who have experienced sexual violence.

The findings here confirm the importance of social rather than individual resilience processes in the school. The students' comments on educational engagement and their critiques of the conservative school model that allows little space to pursue social goals indicate that they value social support and recognize its importance to confident participation and help seeking. However, our findings on the key role of altruism suggests an inversion of the role of social support as it is typically explained in the literature; that is, the young people give more emphasis to supporting others rather than received support.

The study highlights how school structures and practices may enhance trajectories of resilience and intensify trajectories of vulnerability. The interrelationship of these trajectories is dialectical rather than separate sets of factors and processes. For example, scarce resources and conservative models may impact on meaningful activities and disrupt processes of empowerment (academic support and engagement) and opportunities (participation, decision-making) that are critical to strengthen resilience and disrupt processes of vulnerability. There is another ironic dialectic here, in that discriminatory practices and individualized failure may contribute to the development of altruism in a protagonistic resilience (Liborio \& Ungar, 2014) sense of agentic struggle. In this instance, there may be cascading effects of vulnerabilities giving rise to an altruistic resilience because it taps into and reframes traces of disempowerment experienced in past sexual violence (Kia-Keating et al., 2010) and present thwarted opportunities for meaningful cultural and social projects. Altruism then is a form of self-empowerment as it articulates meaningful redress of injustice through a socio-political standpoint (Tseris, 2013b). At the same time, empathizing with others' suffering and taking action elicits young people's realization of their own strengths, their capacity to make change and may help them to discard any lingering identity as "damaged" (Harvey, 1996). However, it is 
clear that opportunities for meaningful social action are important to these young people and bringing them into the curriculum may strengthen altruistic concern for social justice in other ways.

Discriminatory practices and individualized failure should be addressed and this will require increased opportunities for student decision-making and pursuit of their interests in academic curriculum and extracurricular activities. While altruism is important to resilience in this context, it should be strengthened through inclusive school practices (not elicited as response to discrimination) and more opportunities for meaningful activities (Clarke, 2014; Kirk et al., 2015).

\section{FINAL CONSIDERATIONS}

In the last two decades, research and social movements have contributed to a broader comprehension of sexual violence, and the diversity of investigative approaches from different areas of science has helped to build knowledge and innovative practice in health, education, social work or related settings, to serve those who have been victimized. This small-scale study, though not generalizable, contributes to understanding how schools may foster resilience in this unique population.

Noteworthy is the fact that any adolescent in situations of sexual exploitation have participated in the qualitative phase of the study. As the survey inclusion criterion was designed to identify resilient participants, it might reasonably be assumed that these resilience processes would manifest as protective factors within the school setting. Surprisingly, however, participants reported many vulnerability factors in their school experiences. It may be that their overall resilience as revealed by the survey results is accounted for by personal strengths or interpersonal relationships outside of the school setting, rather than by contextual factors within the school experience. The school-based vulnerabilities revealed by the interview data reveal the need for further investigations on how schools can support students who have been victims of sexual violence, rather than compounding their risk.

The literature on resilience identifies schools as a protective factor for children and adolescents with a history of sexual violence. For example, in a review of 50 peer-reviewed manuscripts on factors promoting resilience following childhood sexual abuse, Marriott et al. (2014) found that positive teacher relationships, high academic achievement, strong educational attainment, and a positive future orientation contribute to the development of resilience. Williams 
and Nelson-Gardell (2012) also found that school engagement predicted resilience in a population of sexually abused adolescents. The findings of this paper confirm the importance of meaningful school engagement; however, they problematize the notion that schools universally serve as protective safe havens for youth. Actually, the interviews demonstrated situations in which the school introduces other risk factors that may have the potential to intensify the negative effects of the sexual abuse suffered by the adolescents. These findings open space for a renewed discourse on the role of schools in fostering positive development within this unique student population. For example, Brown, Brack, and Mullis (2008) suggest the need for schools to establish a sense of safety, security, and predictability for youth who have been victims of sexual violence, in order to minimize anxiety emerging from the distrust and lack of control they may have experienced related to their abuse. It may be important for schools to consider how they are establishing such nurturing environments, which could be helpful for a variety of atrisk youth including those affected by sexual violence. The findings of the present study suggests that adequate resources, meaningful utilization of them, and pedagogies reflecting shared responsibility for academic achievement are all important components of the school environment that need attention.

The study also revealed the ability of adolescents to critically position themselves in relation to different practices in the school environment. The possibility to express oneself and to oppose to the institutional dynamic illustrates the presence of a critical sense that can enable the adolescent to participate socially at different levels. However, when schools disregard students' participation, the institution's conservative structures may contribute to the consolidation of asymmetric hierarchies and demarcations of power, such as the dynamics present in the sexual abuse itself.

\section{REFERENCES}

ASBAHR, F. S. F. (2011). Por que aprender isso, professora? Sentido pessoal e atividade de estudo na psicologia histórico-cultural. Tese de doutorado, Universidade de São Paulo, São Paulo.

BANYARD, V. (1999). Childhood maltreatment and the mental health of low-income women. American Journal of Orthopsychiatry, 69(2), 161-171.

BECKETT, H., \& SCHUBOTZ, D. (2014). Young people's self-reported experiences of sexual exploitation and sexual violence: A view from Northern Ireland. Journal of Youth Studies, 17, 430-445.

BOLZAN, N., \& GALE, F. (2011). Using an interrupted space to explore social resilience with marginalized young people. Qualitative Social Work, 11(5), 502-516. 
BOTTRELL, D. (2007). Resistance, resilience and social identities: Reframing "problem youth" and the problem of schooling. Journal of Youth Studies, 10, 597-616.

BOTTRELL, D. (2009). Understanding 'marginal' perspectives towards a social theory of resilience. Qualitative Social Work, 8(3), 321-339.

BOTTRELL, D., \& ARMSTRONG, D. (2012). Local resources and distal decisions: The political ecology of resilience. In M. Ungar (Ed.), The social ecology of resilience: A bandbook of theory and practice (pp. 247-264). New York: Springer.

BRINO, R. F., \& WILLIAMS, L. C. A. (2009). A escola como agente de prevenção do abuso sexual infantil. São Carlos: Suprema.

BRINO, R. F., \& WILLIAMS, L. C. A. (2008). Professores como agentes de prevenção de abuso sexual infantil. Revista Educação e Realidade, 33(2), 209-229.

BROOKS, F. M., MAGNUSSON, J., SPENCER, N., \& MORGAN, A. (2012). Adolescent multiple risk behaviour: An asset approach to the role of family, school and community. Journal of Public Health, 34(1), 48-56.

BROWN, S.D., BRACK, G., \& MULLIS, F.Y. (2008). Traumatic symptoms in sexually abused children: Implications for school counselors. Professional School Counselor, 11, 368-379.

BROWNE, A., \& FINKELHOR, D. (1986). Impact of child sexual abuse: A review of the research. Psychological Bulletin, 99(1), 66-77.

CALHOUN, L. G., \& TEDESCHI, R. G. (Eds.). (2006). Handbook of posttraumatic growth. Mahwah, NJ: Erlbaum.

CARMODY, M. (2009). Conceptualising theprevention of sexual assault and the role of education. Issues Paper No 10, Australian Centre for Study of Sexual Assault. Melbourne: Commonwealth of Australia.

CARROLL-LIND, J., CHAPMAN, J., \& RASKAUSKAS, J. (2011). Children's perceptions of violence: The nature, extent and impact of their experiences. Social Policy Journal of New Zealand, 37, 7-18.

CLARK, I. (2014). Equitable learning outcomes: Supporting economically and culturally disadvantaged students in 'formative learning environments'. Improving Schools, 17(1), 116-126.

COLLISHAW, S., PICKLES, A., MESSER, J., RUTTTER, M., SHEARER, C., \& MAUGHAN, B. (2007). Resilience to adult psychopathology following childhood maltreatment: Evidence from a community sample. Child Abuse \& Neglect, 31(3), 211-229.

DEB, S., \& WALSH, K. (2012). Impact of physical, psychological, and sexual violence on social adjustment of school children in India. School Psychology International, 33(4), 391-415.

DUTRA-THOMÉ, L., SANTOS, E. C., \& KOLLER, S. H. (2011). Exploração sexual e trabalho na adolescência: um estudo de caso. Universitas Psychologica, 10(3), 881-896.

EDMOND, T., AUSLANDER, W., ELZE, D., \& BOWLAND, S. (2006). Signs of resilience in sexually abused adolescent girls in the foster care system. Journal of Child Sexual Abuse, 15(1), 1-28. Estatuto da Criança e do Adolescente (1990). Diário Oficial da União. Lei Federal no 8.069, de 13 de julho de 1990, Brasília, DF.

FALEIROS, V. P., \& FALEIROS, E. S. (2008). Escola que protege: enfrentando a violência contra crianças e adolescentes. Brasília: Ministério da educação.

GILLIGAN, R. (2000). Adversity, resilience and young people: The protective value of positive school and spare time experiences. Children \& Society, 14(1), 37-47.

HABIGZANG, L. F., RAMOS, M. S., \& KOLLER, S. H. (2011). A revelação de abuso sexual: as medidas adotadas pela rede de apoio. Psicologia: Teoria e Pesquisa, 27(4), 467-473. 
HARPER, K., STALKER, C., PALMER, S., \& GADBOIS, S. (2005). Experiences of adults abused as children after discharge from inpatient treatment: Informal social support and self-care practices related to trauma recovery. Families in Society: The Journal of Contemporary Social Services, 86(2), 217-225.

HARVEY, M. (1996). An ecological view of psychological trauma and trauma recovery. Journal of Traumatic Stress, 9(1), 3-23.

HÉBERT, M., LAVOIE, F., \& BLAIS, M. (2013). Post-traumatic stress disorder/PTSD in adolescent victims of sexual abuse: Resilience and social support as protection factors. Ciência \& Saúde Coletiva, 19(3), 685-694.

HENDERSON, N. (2012). Resilience in schools and curriculum design. In M. Ungar (Ed.), The social ecology of resilience: A handbook of theory and practice (pp. 297-306). New York: Springer. HOWELL, K. H. (2011). Resilience and psychopathology in children exposed to family violence. Aggression and Violent Behavior, 16(6), 562-569.

JANOFF-BULMAN, R. (2006). Schema-change perspectives on posttraumatic growth. In L. G. Calhoun \& R. G. Tedeschi (Eds.), Handbook of posttraumatic growth (pp. 81-99). Mahwah, NJ: Erlbaum.

JORDAN, L. (2002). A narrative analysis of the influence of child sexual abuse and subsequent therapy on the self-concept of five adult survivors. M.Sc (Counselling \& Psychology) Thesis. Roehampton: University of Surrey.

JORDAN, L. (2009). Relational trauma. In R. Woolfe, W. Dryden, S. Stawbridge, \& B. Douglas (Eds.), Handbook of Counselling Psychology, (pp. 235-256). London: Sage.

KIA-KEATING, M., SORSOLI, L., \& GROSSMAN, F. (2010). Relational challenges and recovery processes in male survivors of childhood sexual abuse. Journal of Interpersonal Violence, 25(4), 666-683.

KIRK, C., LEWIS, R., BROWN, K., KARIBO, B., ANGELA SCOTT', A., \& PARK, E. (2015). The empowering schools project: Identifying the classroom and school characteristics that lead to student empowerment. Youth \& Society, 1-21. doi: 10.1177/0044118X14566118.

KREMER, I., ORBACH, I., \& ROSENBLOOM, T. (2013). Body image among victims of sexual and physical abuse. Violence and Victims, 28(2), 259-273.

KOLLER, S. H. (2004). Ecologia do Desenvolvimento Humano: pesquisa e intervenção no Brasil. São Paulo: Casa do Psicólogo.

LEECH, T., \& LITTLEFIELD, M. (2011). Social support and resilience in the aftermath of sexual assault. In T. Bryant-Davis (Ed.), Surviving sexual violence: A guide to recovery and empowerment (pp. 296-317). Lanham, MD: Rowman \& Littlefield.

LUSTER, T., \& SMALL, S. (1997). Sexual abuse history and problems in adolescence: Exploring the effects of moderating variables. Journal of Marriage and Family, 59(1), 131-142.

MARRIOTT, C., HAMILTON-GIACHRITSIS, C., \& HARROP, C. (2014). Factors promoting resilience following child sexual abuse: A structured, narrative review of the literature. Child Abuse Review, 23, 17-34.

MARTIN, A. J., \& MARSH, H. W. (2006). Academic resilience and its psychological and educational correlates: A construct validity approach. Psychology in the Schools, 43(3), 267-282. MASTEN, A. S. (2014a). Ordinary magic: Resilience in development. New York, NY: Guiford Press. MASTEN, A. (2014b). Global perspectives on resilience in children and youth. Child Development, 85(1), 6-20. 
MASTEN, A., HERBERS, J., CUTULI, J., \& LAFAVOR, T. (2008). Promoting competence and resilience in the school context. Professional School Counseling, 12(2), 76-84.

MATON, K. (2008). Empowering community settings: Agents of individual development, community betterment, and positive social change. American Journal of Community Psychology, 41(1-2), 4-21.

MATHEWS, B. (2010). Teachers reporting child sexual abuse: Towards evidence-based reform of law, policy and practice. Brisbane: University of Technology.

MCELVANEY, R., GREENE, S., \& HOGAN, D. (2011). Containing the secret of child sexual abuse Journal of Interpersonal Violence, 27(6), 1155-1175.

MORRISON, P., NIKOLAJSKI, C., BORRERO, S., \& ZICKMUND, S. (2014). Youth perspectives on risk and resiliency: A case study from Juiz de Fora, Brazil. Youth \& Society, 46(4), 505-528.

NELSON, B. D., COLLINS, L., VANROOYEN, M. J., JOYCE, N., MUKWEGE, D., \& BARTELS, S. (2011). Impact of sexual violence on children in the Eastern Democratic Republic of Congo. Medicine, Conflict and Survival, 27(4), 211-225.

NOLTEMEYER, A., \& BUSH, K. (2013). Adversity and resilience: A synthesis of international research. School Psychology International, 34, 474-487.

OLIVEIRA, R. P., \& ARAÚJO, G. C. (2005). Qualidade do ensino: uma nova dimensão da luta pelo direito à educação. Revista Brasileira de Educação, 28, 5-23.

PARO, V. H. (2011). Crítica da estrutura da escola. São Paulo: Cortez.

PESCE, R. P., ASSIS, S. G., SANTOS, N., \& OLIVEIRA, R. V. C. (2004). Risco e Proteção: um equilíbrio promotor de resiliência. Psicologia Teoria e Pesquisa, 20(2), 135-143.

PESSOA, A. S. G. (2011). O papel da escola na vida de adolescentes vítimas de violência sexual: risco e proteção. Dissertação de Mestrado, Universidade Estadual Paulista, Presidente Prudente, São Paulo.

PFEIFFER, L., \& SALVAGNI, E. P. (2005). Current view of sexual abuse in childhood and adolescence. Jornal de Pediatria, 81(5), 197-204.

POLUSNY, M., \& FOLLETTE, V. (1995). Long-term correlates of child sexual abuse: Theory and review of the empirical literature. Applied and Preventive Psychology, 4(3), 143-166.

RICARDO, C., \& BARKER, B. (2008). Men, masculinities, sexual exploitation and sexual violence: A literature review and call for action. Rio de Janeiro: Promundo and MenEngage.

RODRIGUES, J. L., BRINO, R. F., \& WILLIAMS, L. C. A. (2006). Concepções de sexualidade entre adolescentes com e sem histórico de violência sexual, Paidéia, 16(34), 229-240.

SAPIENZA, G., \& PEDROMÔNICO, M. R. M. (2005). Risco, proteção e resiliência no desenvolvimento da criança e do adolescente. Psicologia em Estudo, 10(2), 209-216.

SELIGMAN, M. E. P. (2011). Florescer: Uma nova compreensão sobre a natureza da felicidade e do bem-estar (C. P. Lopes, Trad.). Rio de Janeiro: Objetiva.

SOOSAI-NATHAN, L., NEGRI, L., \& FAVE, A. D. (2013). Beyond pro-social behaviour: An exploration of altruism in two cultures. Psychological Studies, 58(2), 103-114.

STRAUSS, A., \& CORBIN, J. (1990). Basics of qualitative research: Grounded theory procedures and techniques. London: Sage.

TRAVIS, R., \& LEECH, T. (2013). Empowerment-based positive youth development: A new understanding of healthy development for African American youth. Journal of Research on Adolescence, 24(1), 93-116. 
TREMBLAY, C., HÉBERT, M., \& PICHÉ, C. (1999). Coping strategies and social support as mediators of consequences in child sexual abuse victims. Child Abuse \& Neglect, 23(9), 929-945.

TSERIS, E. (2013a). Trauma theory without feminism? Evaluating contemporary understandings of traumatized women. Feminism \& Psychology, 28(2), 153-164.

TSERIS, E. (2013b). Beyond symptoms: Towards a narrative conceptualisation of women who have experienced trauma. In F. Davies \& L. Gonzalez (Eds.), Madness, women and the power of art, (pp. 25-43). United Kingdom: Inter-Disciplinary Press.

UNGAR, M. (2008). Resilience across cultures. British Journal of Social Work, 38(2), 218-235.

UNGAR, M., BROWN, M., LIEBENBERG, L., OTHMAN, R., KWONG, W. M., ARMSTRONG, M., \& GILGUN, J. (2007). Unique pathways to resilience across cultures. Adolescence, 42(166), 287-310.

UNGAR, M., \& LIEBENBERG, L. (2011). Assessing resilience across cultures using mixed methods: Construction of the Child and Youth Resilience Measure. Journal of Mixed Methods Research, 5(2), 126-149.

WILLIAMS, J., \& NELSON-GARDELL, D. (2012). Predicting resilience in sexually abused adolescents Child Abuse \& Neglect, 36, 53-63.

YUNES, M. A. M. (2003). Psicologia positiva e resiliência: o foco no indivíduo e na família Psicologia em Estudo, 8, 75-84.

YUNES, M. A. M., \& SZYMANSKI, H. (2001). Resiliência: Noção, conceitos afins e considerações críticas. In Tavares, J. (Ed.). Resiliência e educação (pp. 13-42). São Paulo: Cortez. WERNER, E. (1993). Risk, resiliency and recovery: Perspectives from the Kauai Longitudinal Study. Development and Psychopathology, 5(4), 503-515.

ZHU, Q., GAO, E., CHUANG, Y.L., ZABIN, L.S., EMERSON, M.R., \& LOU, C. (2015). Child sexual abuse and itse relationship with health risk behaviors among adolescents and young adults in Taipei. Asia Pacific Journal of Public Health, 27(6), 643-651.

ZINS, J., ELIAS, M., \& MAHER, C. (EDS.). (2007). Bullying, victimization and peers harassment. $A$ bandbook of prevention and intervention. Abingdon: Routledge.

\section{NOTE}

${ }^{1}$ Project granted by Sao Paulo Research Foundation - Fapesp (2008/56913-6)

Submission: $15 / 12 / 2015$

Approbation: 03/01/2017

Contact:

Alex Sandro Gomes Pessoa

Raposo Tavares Road, Km 572

ZIP CODE: 19067-175

Psychology Department and Graduate Program in Education

The University of Western São Paulo (UNOESTE)

Presidente Prudente, Sao Paulo, Brazil 